\begin{tabular}{ccc}
\hline Journal of Educational Social Studies \\
JESS $9(2)(2020): 44-52$
\end{tabular}

\title{
Pattern of Resident Movement and Mobility From the Area of Origin to the City (Case Study in Mranggen District)
}

\author{
Naufal Haidar Ahmada ${ }^{\bowtie}$, Yudi Basuki \\ Universitas Diponegoro, Indonesia
}

\begin{tabular}{l}
\hline Article Info \\
\hline History Articles \\
Received: \\
11 September 2020 \\
Accepted: \\
7 November 2020 \\
Published: \\
17 December 2020 \\
\hline Keywords: \\
Mobility, Movement, Region \\
\hline
\end{tabular}

\begin{abstract}
The border areas of villages and cities are areas that intersect and influence each other. This was the case between Mranggen District and Semarang City. The development of Mranggen is growing rapidly along with the city of Semarang. All of this has the potential to cause changes in regional characteristics both spatially and socio-economically. This phenomenon is indicated by an increase in population, socio-economic activities as a result of increased population mobility from Mranggen to Semarang and vice versa. The purpose of this study was to analyze the movement and mobility factors of the existing population in terms of age, education level, occupation, income and expenditure and distance. This study uses crosstab sampling analysis to determine the level of relationship and population mobility that occurs. The benefit of this research is to provide input to relevant stakeholders in planning this area
\end{abstract}




\section{INTRODUCTION}

The area between the village and the city, in this case the suburbs will always intersect. On one side of the area displays urban characteristics and the other side displays a rural side. The rapid pace of Mranggen District, which is directly adjacent to the city of Semarang, has the potential for changes in regional characteristics both spatially and socio-economically, because Mranggen District is located in the middle as a link between Semarang City and Demak Regency (Rahayu, 2013). The spread of urban development to rural areas in the suburbs is caused by limited land and urban activities, which in turn can lead to the development of periurban areas and extend to the outskirts of the city (Kurnianingsih \& Rudiarto, 2014). City development which is marked by increasingly dense population and activity is a spatial phenomenon that continues to develop increasingly large land growth (Putra \& Pradoto, 2016). This phenomenon is indicated by an increase in population, socio-economic activities and population mobility from outside the city to the outskirts of the city. The increase in population activity is marked by the rapid development of areas within the city. The limited land area in the city will make the city experience a shift to the suburbs, this is due to the increasing need for residential land and infrastructure for activities that are increasingly expanding (Suprapta, 2006).

The relationship between urban villages is caused by high population growth rates, one of which is due to the mobility of the population. People who do mobility are divided into two, namely permanent and non-permanent mobility. Permanent mobility, which is when the population moves from their original area to a new area so that they change their residential status. Meanwhile, non-permanent mobility is the movement of people from one area to another but they do not intend to stay in the destination (Mantra, 2000). The impact that occurs due to population movement is the gap between urban and rural areas. This situation will cause various problems, such as widening socio-economic disparities, increasing urbanization and obstructing development in rural areas. (Wibiseno, 2002) To anticipate the aforementioned conditions, development between cities and villages should be carried out in an integrated manner so that the interactions that occur are mutually beneficial (Krismasta, Rogi, \& Tilaar, 2015). Mranggen District plays a role as a satellite area in Demak Regency because it is the main route for population movement from Mranggen to Semarang. The goals carried out to achieve these goals are to analyze the movement patterns and mobility of the population according to the pull and push factors. The driving factors are the lack of employment in the village, low wages, minimal public facilities, restrictive customs, and motives for seeking experience, while the pull factors are high wages, lots of employment, easy public facilities, free lifestyle, and easy transportation (Niari, 2013). Once the factors are known, data collection will be carried out randomly to see the condition of the sources in the field, so that the data found can be used as a government study in equitable development.

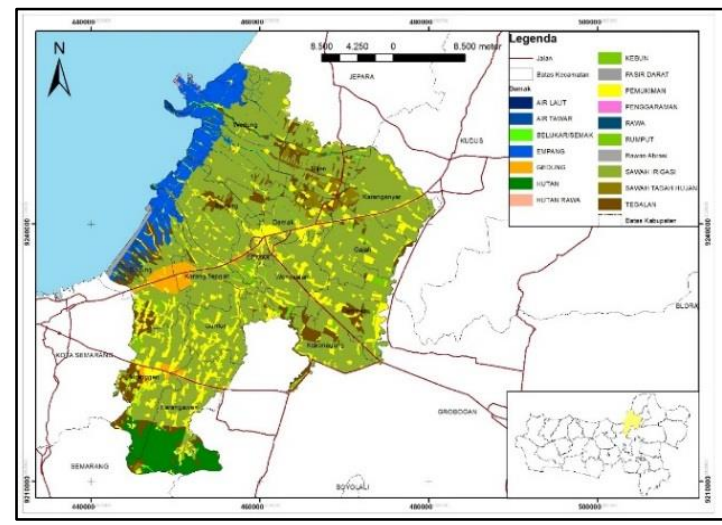

Figure 1. Map of the Mranggen Disctrict

Where the boundaries are as follows in North is Sayung District; South is Semarang Regency; West is Pedurungan District and Semarang City; East is Karangawen District and Guntur District (Figure 1).

Interaction is a process of mutual influence between two things. In addition, the term interaction is also associated with space, so the process also affects each other between the spaces 
in question. Ullman argues that spatial interaction emphasizes regional interdependence and implies movement of commodities, both, society, information, etc. between regions (Yunus, 2010). In addition, there is also a comparison of the areas under study. Hadi Sabari Yunus said that at least two regions had to be compared. The aim is to determine the strengths and weaknesses that exist in each region to determine regional development policies (Yunus, 2008).

In Mranggen District itself, there are several pull and push factors according to the above criteria. Where in the city of Semarang has relatively more supportive and decent work opportunities, as well as earning more income which allows for a better life. As for residential facilities, they tend to choose Mranggen District because of the proximity to Semarang City and the friendlier land prices compared to Semarang City. For more details, it can be seen in the following image (Fenton \& van Lerven, 2012).

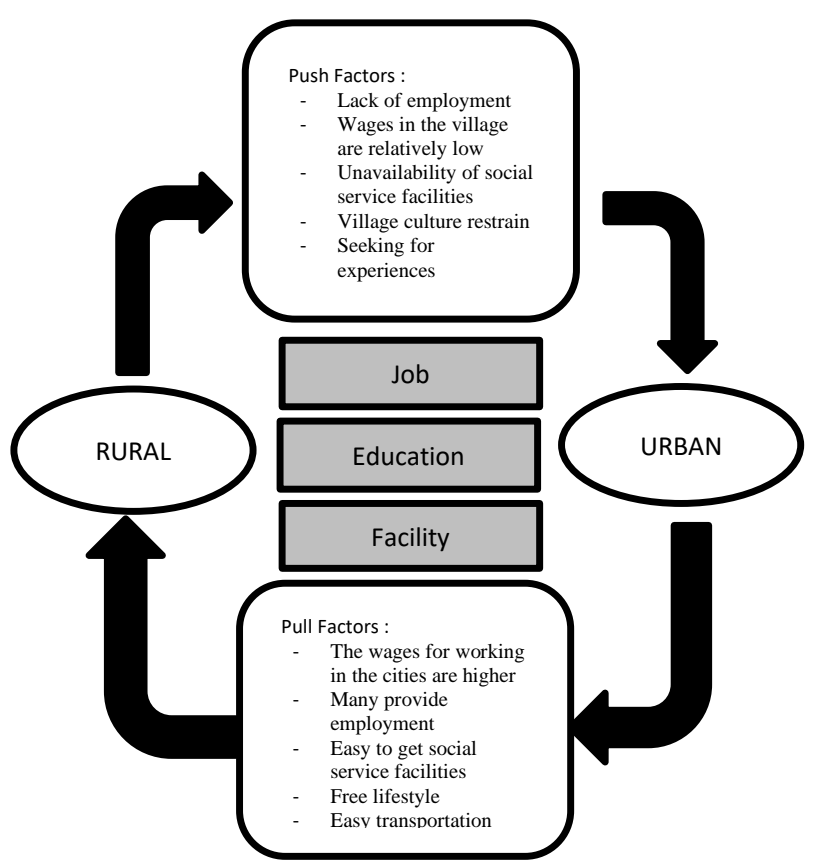

Figure 2. Push and Pull Factors

Source : Action Against Hunger, 2012

There are two types of population mobility within a city, namely vertical population mobility and horizontal population mobility. Population mobility is often referred to as a change in status, one example is a change in employment status.
Meanwhile, population mobility is often referred to as geographic population mobility, namely population movement across borders to other areas within a certain period of time (Indrareni \& Rakhmatulloh, 2013). The following is a summary of the forms of population mobility:

Table 1. Forms of Mobility

\begin{tabular}{|c|c|c|c|}
\hline No & $\begin{array}{l}\text { Mobility Area } \\
\text { Form }\end{array}$ & Time of & Mobility \\
\hline 1 & Commuting & Village & $\begin{array}{l}6 \text { hours or } \\
\text { more then } \\
\text { go home in } \\
\text { the same } \\
\text { day }\end{array}$ \\
\hline 2 & $\begin{array}{l}\text { Overnight } \\
\text { boarding at the } \\
\text { destination }\end{array}$ & Village & $\begin{array}{l}\text { More than } \\
\text { one day } \\
\text { but not } \\
\text { more than } \\
6 \text { months }\end{array}$ \\
\hline 3 & $\begin{array}{l}\text { Permanent } \\
\text { residence }\end{array}$ & Village & $\begin{array}{l}6 \text { months } \\
\text { or more } \\
\text { staying in } \\
\text { the } \\
\text { destination }\end{array}$ \\
\hline
\end{tabular}

Horizontal population mobility consists of permanent mobility and non-permanent mobility. Permanent population mobility is known as migration. Meanwhile,non-permanent population mobility is divided into two, namely living / boarding and commuting (Mardhotillah \& Sariffuddin, 2016). The purpose of this study is to provide a clearer picture of the level of relationship between the urban villages between Mranggen District and Semarang City in terms of several related factors. Namely: factors of age, education, occupation, income and expenditure and distance.

\section{METHODS}

This study uses an approach to a population whose data is studied based on sample data by conducting interviews and observing the object of research. To determine the relationship between urban villages in Mranggen District, the 
type of research approach used is a quantitative method.

This research belongs to the type of deductive research where this research studies facts by searching for the right truth. This research studies problems that arise in society in certain situations relating to relationships, activities, attitudes, views, and influences that occur. The purpose of deductive research is to obtain information about the current state and see the relationship with existing variables. This research is often used in decision making in determining policy in problem solving (Rukajat, 2018). The deductive research is used here because of the scope of the study which revealed the true relationship of activities in the city.

The substantial scope of this study includes several variable factors in the problem of migration decisions :

1. Age, the age level of migrants from the area of origin who perform mobility.

2. Education level of migrants, the level of education of migrants from areas of origin that can influence mobility decisions.

3. Occupation, the type of migrant work at the destination.

4. Distance, how far the migrant is in mobility.

5. Income and expenditure, the economic factors that are proportional to the expenditure and income of migrants.

In conducting a deductive approach here is carried out through interviews, either direct observation or observing events and conclusions are drawn from these two things. Data collection techniques will complement primary and secondary data (Aini, 2015). Primary data is obtained from observations and interviews with community leaders who live there, both village heads, chief heads, and residents who carry out migration activities. For secondary data obtained from various documentation and articles about the activities carried out by these residents. The data used are in the form of questionnaire interviews with migrant actors (Nurdiani, 2014).

In sampling technique, respondent taking is using crosstab sampling technique, which is taking a number of cases through the relationship between one person and another person or one case with another case, then looking for further relationships through the same process, to find a saturation point where the answer what the resource person said was the same as the previous answer with a focus on specific criteria: focus on commuters who had carried out these activities at least the last few months or years. The tool used is the SPSS 20 program using Chi-Square. Crosstab sampling analysis is used here to analyze the interaction in the form of population mobility from Mranggen District to the City of Semarang so that it can identify the relationship between urban villages through the variable like age, education, occupation, distance, income and expenditure.

\section{RESULT AND DISCUSSION}

\section{Patterns of Population Movement and Mobility in Mranggen}

This chapter will discuss the analysis of mobility and movement in Mranggen District. The results of this study were obtained through direct observation or observation at the location of the long-lived community. Public perceptions of the relationship to the city system are influenced by various factors, such as age, education, employment, length of time to leave, income and expenditure. In accordance with the theory of Action Against Hunger (Fenton \& van Lerven, 2012) where the driving and pulling factors of population migration to cities are the key to population movement.

The respective respondents who involved in the each sub-district of Mranggen District are Bandungrejo (3,9\%); Banyumeneng (7,8 \%); Batursari (7,8 \%); Brumbung (3,9\%); Candisari (3,9 \%); Jamus (3,9 \%); Kalitengah (3,9 \%); Kangkung (7,8 \%); Karangsono (7,8 \%); Kebonbatur (7,8 \%); Kembangarum (5,9\%); Menur (2,0 \%); Mranggen (7,8 \%); Ngemplak (3,9\%); Sumberejo (7,8\%); Tamansari (3,9\%); Tegalarum (3,9\%); Waru (2,0\%); Wringinjajar $(3,9 \%)$. The total of respondents are 51 persons.

The characteristic of responent here can be divided into several factors, namely age, education, occupation, income and expenditure and distance. 
a. Age

Age, namely the age level of migrants from the area of origin who perform mobility

Table 2. Chi-Square Tests for Age

\begin{tabular}{llll}
\hline Field & Value df & $\begin{array}{l}\text { Asymptotic } \\
\text { Significance } \\
\text { (2-sided) }\end{array}$ \\
\hline $\begin{array}{l}\text { Pearson Chi-Square } \\
\text { Likelihood Ratio }\end{array}$ & $65,931^{\text {a }}$ & 36 &, 002 \\
$\begin{array}{l}\text { Linear-by-Linear } \\
\text { Association }\end{array}$ & 1,433 & 36 &, 052 \\
N of Valid Cases & 51 &, 231 \\
$\begin{array}{l}\text { a. } 57 \text { cells (100,0\%) have expected count less than 5. The } \\
\text { minimum expected count is }, 06 .\end{array}$
\end{tabular}

Chi-square test shows a significant $\mathrm{p}$-value of 0,002 (less than 0,05 ) for the relationship between age and the decisions of migration (Table 3).

Table 3. Symmetric Measures for Age

\begin{tabular}{|c|c|c|c|c|c|}
\hline & Field & Value & $\begin{array}{c}\text { Asymptotic } \\
\text { Standardized } \\
\text { Error }^{\mathrm{a}} \\
\end{array}$ & $\underset{T^{\mathrm{b}}}{\text { Approximate }}$ & $\begin{array}{l}\text { Approximate } \\
\text { Significance }\end{array}$ \\
\hline \multirow{3}{*}{$\begin{array}{l}\text { Nominal } \\
\text { by } \\
\text { Nominal }\end{array}$} & Phi & 1,137 & & & ,002 \\
\hline & Cramer's V & ,804 & & & ,002 \\
\hline & $\begin{array}{l}\text { Contingency } \\
\text { Coefficient }\end{array}$ & ,751 & & & ,002 \\
\hline $\begin{array}{l}\text { Interval } \\
\text { by } \\
\text { Interval }\end{array}$ & Pearson's R & 169 & 144 & 1,203 &, $235^{c}$ \\
\hline $\begin{array}{l}\text { Ordinal } \\
\text { by } \\
\text { Ordinal }\end{array}$ & $\begin{array}{l}\text { Spearman } \\
\text { Correlation }\end{array}$ & , 105 & 153 & ,739 &, $463^{\mathrm{c}}$ \\
\hline $\mathrm{N}$ of Valid & d Cases & 51 & & & \\
\hline
\end{tabular}

The symmetric measures above shows significant $p$-value of 0,002 (less than 0,05 ). This means that there is a relationship between age and decisions of migration. In other words, increasing age will affect migrant decisions (Table 4).

b. Education Level

Migrant education level, namely the education level of migrants from the area of origin that can influence mobility decisions
Table 4. Chi-Square Tests for Education Level

\begin{tabular}{|c|c|c|c|}
\hline Field & Value & $\mathrm{df}$ & $\begin{array}{l}\text { Asymptotic } \\
\text { Significance } \\
\text { (2-sided) }\end{array}$ \\
\hline Pearson Chi-Square & $32,658^{a}$ & 36 & 628 \\
\hline Likelihood Ratio & 28,596 & 36 & ,805 \\
\hline $\begin{array}{l}\text { Linear-by-Linear } \\
\text { Association }\end{array}$ & 4,175 & 1 &, 041 \\
\hline $\mathrm{N}$ of Valid Cases & 51 & & \\
\hline \multicolumn{4}{|c|}{$\begin{array}{l}\text { a. } 57 \text { cells }(100,0 \%) \text { have expected count less than } 5 \text {. } \\
\text { The minimum expected count is }, 02 \text {. }\end{array}$} \\
\hline $\begin{array}{l}\text { Chi-square } t \\
\text { of } 0,628 \text { (greater } t \\
\text { between education } \\
\text { (Table 5). }\end{array}$ & $\begin{array}{l}\text { t show } \\
\text { an } 0,05 \\
\text { evel an }\end{array}$ & 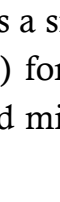 & $\begin{array}{l}\text { cant p-value } \\
\text { relationship } \\
\text { on decisions }\end{array}$ \\
\hline
\end{tabular}

Table 5. Symmetric Measures for Education

\begin{tabular}{|c|c|c|c|c|c|}
\hline & & & Level & & \\
\hline & & $\begin{array}{c}\text { Valu } \\
\text { e }\end{array}$ & $\begin{array}{c}\text { Asymptotic } \\
\text { Standardiz } \\
\text { ed Error }^{\mathrm{a}}\end{array}$ & $\begin{array}{l}\text { Approxim } \\
\text { ate } \mathrm{T}^{\mathrm{b}}\end{array}$ & $\begin{array}{c}\text { Approxim } \\
\text { ate } \\
\text { Significan } \\
\text { ce }\end{array}$ \\
\hline & Phi & ,800 & & & ,628 \\
\hline $\begin{array}{l}\text { Nominal } \\
\text { by }\end{array}$ & $\begin{array}{l}\text { Cramer' } \\
\text { s V } \\
\text { Conting }\end{array}$ & ,566 & & & ,628 \\
\hline Nominal & $\begin{array}{l}\text { ency } \\
\text { Coeffici } \\
\text { ent }\end{array}$ & ,625 & & & ,628 \\
\hline $\begin{array}{l}\text { Interval } \\
\text { by } \\
\text { Interval }\end{array}$ & $\begin{array}{l}\text { Pearso } \\
\text { n's R }\end{array}$ & ,289 & ,138 & 2,113 &, $040^{c}$ \\
\hline $\begin{array}{l}\text { Ordinal } \\
\text { by } \\
\text { Ordinal }\end{array}$ & $\begin{array}{l}\text { Spearm } \\
\text { an } \\
\text { Correlat } \\
\text { ion }\end{array}$ & ,299 & ,137 & 2,193 &, $033^{c}$ \\
\hline $\mathrm{N}$ of Valio & Cases & 51 & & & \\
\hline
\end{tabular}

The symmetric measures table above shows a significant $\mathrm{p}$-value of 0,628 (greater than $0,05)$. This means that there is no relationship between education level and migration decisions. In other words, the level of education has no effect on migrant decisions (Table 6).

\section{c. Occupation}

Occupation, namely the type of migrant work at the destination 
Table 6. Chi-Square Tests for Occupation

\begin{tabular}{|c|c|c|c|}
\hline Field & Value & $\mathrm{df}$ & $\begin{array}{l}\text { Asymptotic } \\
\text { Significance } \\
\text { (2-sided) }\end{array}$ \\
\hline Pearson Chi-Square & $45,595^{\mathrm{a}}$ & 36 & 131 \\
\hline Likelihood Ratio & 25,951 & 36 & ,892 \\
\hline $\begin{array}{l}\text { Linear-by-Linear } \\
\text { Association }\end{array}$ & 021 & 1 & ,885 \\
\hline $\mathrm{N}$ of Valid Cases & 51 & & \\
\hline
\end{tabular}

a. 57 cells $(100,0 \%)$ have expected count less than 5 . The minimum expected count is, 02 .

Chi-square test shows a significant p-value of 0,131 (greater than 0,05 ) the relationship between employment and migration decisions (Table 7).

Table 7. Symmetric Measures for Occupation

\begin{tabular}{|c|c|c|c|c|c|}
\hline \multicolumn{2}{|c|}{ Field } & $\begin{array}{c}\text { Valu } \\
\text { e }\end{array}$ & $\begin{array}{c}\text { Asymptotic } \\
\text { Standardize } \\
\text { d Error }\end{array}$ & $\begin{array}{c}\text { Approximat } \\
\qquad \mathrm{eT}^{\mathrm{b}}\end{array}$ & $\begin{array}{c}\text { Approximat } \\
\text { e } \\
\text { Significance }\end{array}$ \\
\hline \multirow{3}{*}{$\begin{array}{l}\text { Nominal } \\
\text { by } \\
\text { Nominal }\end{array}$} & & ,946 & & & ,131 \\
\hline & $\begin{array}{l}\text { Cramer's } \\
\text { V } \\
\text { Continge }\end{array}$ & ,669 & & & 131, \\
\hline & $\begin{array}{l}\text { ncy } \\
\text { Coefficie } \\
\text { nt }\end{array}$ & ,687 & & & 131 \\
\hline $\begin{array}{l}\text { Interval by } \\
\text { Interval }\end{array}$ & $\begin{array}{l}\text { Pearson' } \\
\text { s R }\end{array}$ & ,020 & 151 & 143 &, $887^{\circ}$ \\
\hline $\begin{array}{l}\text { Ordinal by } \\
\text { Ordinal }\end{array}$ & $\begin{array}{l}\text { Spearma } \\
n \\
\text { Correlati } \\
\text { on }\end{array}$ & ,052 & 138 & 366 &, $716^{c}$ \\
\hline \multicolumn{2}{|c|}{$\mathrm{N}$ of Valid Cases } & 51 & & & \\
\hline
\end{tabular}

The symmetric measures table above shows a significant $p$-value of 0,131 (greater than $0,05)$. This means that there is no relationship between employment and migration decisions. In other words, any job does not affect the migrant's decision (Table 8).

d. Distance

Distance, namely how far the migrant is in mobility.

Table 8. Chi-Square Tests for Distance

\begin{tabular}{llll}
\hline Field & Value & df & $\begin{array}{l}\text { Asymptotic } \\
\text { Significance } \\
\text { sided) }\end{array}$ \\
\hline $\begin{array}{l}\text { Pearson Chi-Square } \\
\text { Likelihood Ratio }\end{array}$ & $102,000^{\mathrm{a}}$ & 36 &, 000 \\
$\begin{array}{l}\text { Linear-by-Linear } \\
\begin{array}{l}\text { Association } \\
\text { N of Valid Cases }\end{array}\end{array}$ &, 031 & 129 &, 000 \\
$\begin{array}{l}\text { a. } 57 \text { cells (100,0\%) have expected count less than 5. The minimum } \\
\text { expected count is ,12. }\end{array}$
\end{tabular}

Chi-square test shows a significant $\mathrm{p}$-value of 0,000 (less than 0,05 ) for the relationship between distance and migration decisions (Table 9).

Table 9. Symmetric Measures for Distance

\begin{tabular}{|c|c|c|c|c|c|}
\hline \multicolumn{2}{|r|}{ Field } & Value & $\begin{array}{c}\text { Asymptotic } \\
\text { Standardized } \\
\text { Error }^{\mathrm{a}}\end{array}$ & $\underset{\mathrm{T}^{\mathrm{b}}}{\text { Approximate }}$ & $\begin{array}{l}\text { Approximate } \\
\text { Significance }\end{array}$ \\
\hline \multirow{2}{*}{$\begin{array}{l}\text { Nominal } \\
\text { by } \\
\text { Nominal }\end{array}$} & \multirow{2}{*}{$\begin{array}{l}\text { Phi } \\
\text { Cramer's V } \\
\text { Contingency } \\
\text { Coefficient }\end{array}$} & $\begin{array}{l}1,414 \\
1,000\end{array}$ & & & $\begin{array}{l}, 000 \\
, 000\end{array}$ \\
\hline & & ,816 & & & ,000 \\
\hline \multirow{2}{*}{$\begin{array}{l}\text { Interval } \\
\text { by } \\
\text { Interval } \\
\text { Ordinal } \\
\text { by } \\
\text { Ordinal }\end{array}$} & Pearson's R & ,025 & ,078 & ,174 &, $862^{\mathrm{C}}$ \\
\hline & \multirow[t]{2}{*}{$\begin{array}{l}\text { Spearman } \\
\text { Correlation }\end{array}$} & ,086 & 120 & \multirow[t]{2}{*}{ 603 } & \multirow[t]{2}{*}{, $549^{c}$} \\
\hline $\mathrm{N}$ of Vali & & 51 & & & \\
\hline
\end{tabular}

The symmetric measures table above shows a significant p-value of 0,000 (less than $0,05)$. This means that there is a relationship between distance and migration decisions. The closer the distance traveled, the closer it was and made the migrant not tired on the trip, whereas the farther the distance traveled, the farther the journey would be to migrate (Table 10).

\section{e. Income}

Income, economic factors that are comparable to income of migrants.

Table 10. Chi-Square Tests for Income

\begin{tabular}{llll}
\hline Field & Value & df & $\begin{array}{l}\text { Asymptotic } \\
\text { Significance (2- } \\
\text { sided) }\end{array}$ \\
\hline $\begin{array}{l}\text { Pearson Chi-Square } \\
\text { Likelihood Ratio }\end{array}$ & $37,464^{\mathrm{a}}$ & 36 &, 402 \\
$\begin{array}{l}\text { Linear-by-Linear } \\
\text { Association }\end{array}$ & 5,427 & 1 &, 249 \\
N of Valid Cases & 51 & & \\
\hline $\begin{array}{l}\text { a. } 57 \text { cells (100,0\%) have expected count less than 5. The } \\
\text { minimum expected count is ,22. }\end{array}$
\end{tabular}

Chi-square test shows a significant p-value of 0,402 (greater than 0,05 ) for the relationship between income and migration decisions (Table 11). 
Table 11. Symmetric Measures for Income

\begin{tabular}{|c|c|c|c|c|c|}
\hline \multicolumn{2}{|c|}{ Field } & $\begin{array}{c}\text { Valu } \\
\text { e }\end{array}$ & $\begin{array}{c}\text { Asymptotic } \\
\text { Standardize }\end{array}$ & $\begin{array}{c}\text { Approximat } \\
\mathrm{e} \mathrm{T}^{\mathrm{b}}\end{array}$ & $\begin{array}{c}\text { Approximat } \\
e \\
\end{array}$ \\
\hline \multirow{4}{*}{$\begin{array}{l}\text { Nominal } \\
\text { by } \\
\text { Nominal }\end{array}$} & Phi & ,857 & & &, 402 \\
\hline & Cramer's & 606 & & & ,402 \\
\hline & Continge & & & & \\
\hline & $\begin{array}{l}\text { ncy } \\
\text { Coefficie } \\
\text { nt }\end{array}$ & ,651 & & & 402 \\
\hline $\begin{array}{l}\text { Interval by } \\
\text { Interval }\end{array}$ & $\begin{array}{l}\text { Pearson' } \\
\text { SR } \\
\text { Spearma }\end{array}$ & ,329 & 120 & 2,443 &, $018^{\circ}$ \\
\hline $\begin{array}{l}\text { Ordinal by } \\
\text { Ordinal }\end{array}$ & $\begin{array}{l}\text { n } \\
\text { Correlati } \\
\text { on }\end{array}$ & ,323 & 124 & 2,390 &, $021^{\circ}$ \\
\hline \multicolumn{2}{|c|}{$\mathrm{N}$ of Valid Cases } & 51 & & & \\
\hline
\end{tabular}

The symmetric measures table above shows a significant $p$-value of 0.402 (greater than $0.05)$. This means that there is no relationship between income and migration decisions. In other words, whatever income does not affect the migrant's decision (Table 12).

\section{f. Expenditure}

Expenditure, economic factors that are comparable to expenditure of migrants.

Table 12. Chi-Square Tests for Expenditure

\begin{tabular}{lccc}
\hline \multicolumn{1}{c}{ Field } & Value & df & $\begin{array}{c}\text { Asymptotic } \\
\text { Significance } \\
(2-\text {-sided) }\end{array}$ \\
\hline $\begin{array}{l}\text { Pearson Chi-Square } \\
\text { Likelihood Ratio }\end{array}$ & $47,077^{\text {a }}$ & 36 &, 102 \\
$\begin{array}{l}\text { Linear-by-Linear } \\
\text { Association }\end{array}$ & 39,695 & 36 &, 309 \\
N of Valid Cases & 2,491 & 1 &, 115 \\
\hline $\begin{array}{l}\text { a. } 57 \text { cells (100,0\%) have expected count less than 5. The } \\
\text { minimum expected count is }, 06 .\end{array}$
\end{tabular}

Chi-square test shows a significant $\mathrm{p}$-value of 0,102 (greater than 0,05 ) the relationship between expenditure and migration decisions (Table 13).

Table 13. Symmetric Measures for Expenditure

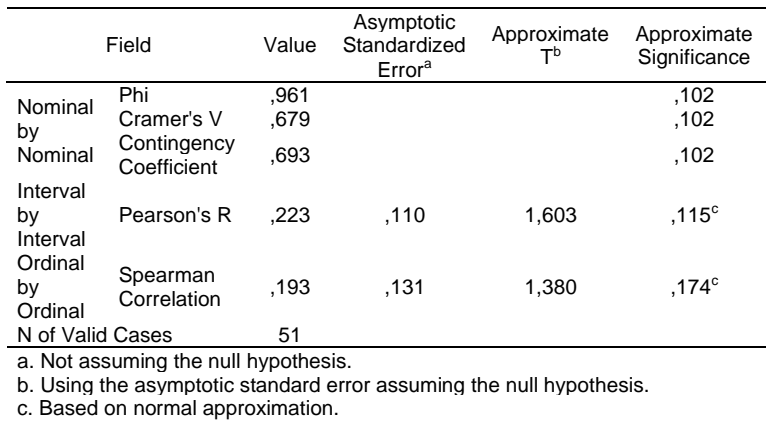

The symmetric measures table above shows a significant $p$-value of 0,102 (greater than $0,05)$. This means that there is no relationship between expenditure and migration decisions. In other words, any expenditure does not affect the migrant's decision (Table 14).

\section{Crosstab Analysis of the Influence of Migrant Movement in Mranggen District to Semarang City}

a. Village Crosstab Analysis by Age

Village crosstab analysis based on age is used to determine the relationship between a person's age and commuter behavior every day. In this study, it is necessary to know what age group is dominant in Mranggen District.

From the results of the village crosstab analysis with age, the chi-square result is 0,002 (less than 0,05 ), this indicates that there is a relationship between age and migration decisions. Based on real conditions in the field, people aged 20-40 years have a higher migration rate than people over 40 and under 20 years. This is equal with theory by

b. Village Crosstab Analysis by Education Level Village crosstab analysis based on education level is used to determine the relationship between a person's education level and commuter behavior every day and if there is, which level of education is dominant in Mranggen District. From the results of the village crosstab analysis with the level of education, the chi-square result is 0,628 (greater than 0,05), this indicates that there is no relationship between education level and migration decisions.

c. Village Crosstab Analysis by Occupation Village crosstab analysis based on occupation is used to determine the relationship between a person's job and commuter behavior every day and if there is, which occupation is dominant in Mranggen District. From the results of the village crosstab analysis with occupation, the chisquare result is 0.131 (greater than 0.05 ), this indicates that there is no relationship between occupation and migration decisions.

d. Village Crosstab Analysis by Distance

Village crosstab analysis based on distance is used to determine the relationship between a person's education level and commuter behavior every day. In this 
research, it is necessary to know which distance is dominant in Mranggen District.

From the results of the village crosstab analysis based on distance, the chisquare result was 0,000 (less than 0,05 ), this indicates that there is a relationship between distance and migration decisions. Based on real conditions in the field, the closest distance to Jalan Raya Mranggen-Semarang, namely Bandungrejo, Batursari, Brumbung, Mranggen, Karangsono, and Kembangarum Villages, does not get any significant obstacles in terms of transportation to support commuter activities. Meanwhile, those who are far away on average use private vehicles such as motorbikes to carry out commuter activities. Non-permanent mobility in Mranggen here could be concluded is the movement of people from one area to another but they do not intend to stay in the destination (Mantra, 2000).

e. Village Crosstab Analysis by Income

Village crosstab analysis based on income is used to determine the relationship between a person's income and commuter behavior every day and if there is, which income is dominant in Mranggen District. From the results of the village crosstab analysis with income, the chi-square result is 0,402 (greater than 0,05 ), this indicates that there is no relationship between income and migration decisions.

f. Village Crosstab Analysis by Expenditure Village crosstab analysis based on expenditure is used to determine the relationship between a person's expenditure and commuter behavior every day and if there is, which expenditure is dominant in Mranggen District. From the results of the village crosstab analysis with expenditure, the chi-square result is 0,102 (greater than 0,05 ), this indicates that there is no relationship between expenditure and migration decisions.

\section{CONCLUSION}

In accordance with the results of the crosstab analysis from SPSS above, where several factors that have been analyzed are the key in population migration activities. Based on the recap results obtained from the district obtained, there are several factors that influence: 1.) age of the migrants referred to in this study is the age at which they carry out mobility activities. The younger the age, the higher the interest in mobility; 2.) The decision to doing mobility depends on the decision on how far the migrant commutes. Residents who are located far from the city of Semarang have a longer time compared to the closest kelurahan from the city of Semarang. This can lead to a problem of different needs, where residents who are far away will take longer to get to Semarang City so that their movement may be minimized. The farther the distance to be addressed, of course the importance of mobility is needed because to reach the destination it takes a long time. The condition of the city that is more feasible causes residents to seek fortune and move from their place of origin, in this case most of the residents in Mranggen District seek a decent living in Semarang City. The behavior of local commuters is still influenced by age and distance and the fact that the level of welfare of residents in rural areas is not evenly distributed, so efforts from the local government are needed to pay more attention to them. Then it is also necessary to provide efficient and affordable public transportation in order to minimize the expenses of residents commuting. Because most of them use motorbikes for work.

\section{REFERENCES}

Aini, S. R. (2015). Analisis Pengawasan Internal Terhadap Kinerja Pegawai Negeri Sipil (Studi Pada Kantor Imigrasi Kelas 1 Bandar Lampung). Fakultas Ilmu Sosial dan Ilmu Politik.

Fenton, L., \& van Lerven, F. (2012). Rural-urban linkages and under-nutrition in Guatemala. Action Against Hunger, (January), 1-4.

Indrareni, A., \& Rakhmatulloh, A. R. (2013). Pengaruh Pergerakan Pekerja Commuter Terhadap Pola Konsumsi di Kecamatan Kaliwungu. Teknik PWK (Perencanaan Wilayah Kota), 2(4), 927-937.

Krismasta, V., Rogi, O. H. A., \& Tilaar, S. (2015). Kajian Transformasi Wilayah 
Peri-urban di Kota Manado (Studi Kasus : Kecamatan Mapanget). Spasial, 2(1), 1-9. Kurnianingsih, N. A., \& Rudiarto, I. (2014) Analisis Transformasi Wilayah PeriUrban pada Aspek Fisik dan Sosial Ekonomi (Kecamatan Kartasura). Jurnal Pembangunan Wilayah \& Kota, 10(3), 265.

Mantra, I. B. (2000). Demografi Umum. Pustaka Pelajar.

Mardhotillah, S., \& Sariffuddin, S. (2016). Population Mobility Characteristic: Notes From The Urban-Urban Interaction In Semarang Metropolitan Region. DIMENSI (Journal of Architecture and Built Environment), 43(2), 115-122.

Niari, R. (2013). Faktor-Faktor Pendorong dan Penarik yang Menyebabkan Penduduk Suku Banten Bermigrasi ke Kelurahan Sukajawa Kecamatan Tanjung Karang Barat Kota Bandar Lampung Tahun 2012. Universitas Lampung.

Nurdiani, N. (2014). Teknik Sampling Snowball dalam Penelitian Lapangan. ComTech, 5(2), 1110-1118.

Putra, D. R., \& Pradoto, W. (2016). Pola Dan

Faktor Perkembangan Pemanfaatan
Lahan di Kecamatan Mranggen, Kabupaten Demak. Jurnal Pengembangan Kota, 4(1), 67.

Rahayu, T. A. (2013). Keterkaitan Kota Demak terhadap Kota Semarang dalam Lingkup Wilayah Metropolitan. Jurnal Wilayah Dan Lingkungan, 1(2), 105-122.

Rukajat, A. (2018). Pendekatan Penelitian Kuantitatif: Quantitative Research Approach (1st ed.). Yogyakarta: Deepublish.

Suprapta. (2006). Ketergantungan Wilayah Kecamatan Mranggen terhadap Kota Semarang. Universitas Diponegoro.

Wibiseno, T. (2002). Kajian Perubahan Penggunaan Lahan Kecamatan Mranggen Kabupaten Demak sebagai Kawasan Pinggiran Kota Semarang.pdf. Universitas Diponegoro, Semarang.

Yunus, H. S. (2008). Dinamika Wilayah Periurban: Determinan Masa Depan Kota. Pustaka Pelajar.

Yunus, H. S. (2010). Metodologi Penelitian Wilayah Kontemporer. Yogyakarta: Pustaka Pelajar. 